\title{
state swings spell howard's end
}

\section{Paul D.Williams}

$\mathrm{I}$ t has become a truism that Australian politics over the past decade have witnessed unprecedented levels of electoral volatility. The major parties have lost ground to minor parties and Independents as voters have grown increasingly disillusioned with the perceived failure of governments to "listen". Recent state election results in Western Australia and Queensland have demonstrated that voters, in their collective pique, now make commonplace swings of a magnitude that, years before, were unimaginable. This article reflects upon these results and, with an eye to the probable issues of the forthcoming federal election, explores a possible future of the Howard Government. In doing so, two arguments are advanced. The first is that policy and current issues are set to play a role more significant than that of leadership itself. And second, that the Liberal and National Party (LNP) Coalition appears at a disadvantage relative to the Australian Labor Party (ALP) Opposition in terms of policies salient to an anxious electorate. In short, the evidence indicates that the Howard Government is set for a significant rebuff at the next federal election.

\section{Western Australia}

Overwhelming evidence for impending electoral disaster for the federal Coalition lies in the results of recent state elections. The first electoral contest of the year, the Western Australian election of 10 February 2001, saw Richard Court's LNP Government defeated in a record 11.2 per cent primary swing with the loss of 14 seats. This result, however, could not be read as a comprehensive endorsement of the ALP Opposition which increased its primary vote only marginally by 1.4 per cent. Instead, minor parties were the principal beneficiaries of a protest vote in which Pauline Hanson's One Nation (PHON) attracted 9.6 per cent and the Greens 7.8 per cent (up 3.1 per cent). Importantly, 'Other' candidates, of which the renegade 'Liberals for Forests' comprised a significant part, won four Lower House seats with 7.9 per cent (up 6.9 per cent) of the

PaulWilliams is at the School of Political Science and International Relations, University of Queensland vote. Three conclusions can be drawn from this result. First, the Coalition, in losing the advantage of incumbency, is no longer perceived as the 'natural' party of government in the west. Second, minor parties on both the left and the right are in a position to capitalize upon the electorate's critical dissatisfaction with both major parties. And third, while the ALP did not enjoy the express confidence of a majority of voters, it did, however, receive the bulk of minor party second preferences to forge a preferred endorsement. By all accounts, the Coalition's position appears tremulous.

\section{Queensland}

The Queensland State election of 17 February 2001 occurred in quite different circumstances. Despite the embarrassing revelations stemming from the Shepherdson Inquiry into vote rorting, Labor Premier Peter Beattie mounted a strongly populist, indeed 'Presidential', campaign from which the ALP emerged with 48.9 per cent (up 10.0 per cent) of the primary vote and with 66 (up 22) of the Legislative Assembly's 89 seats. While the swing against the Coalition was marginal, it must be remembered that the LNP had

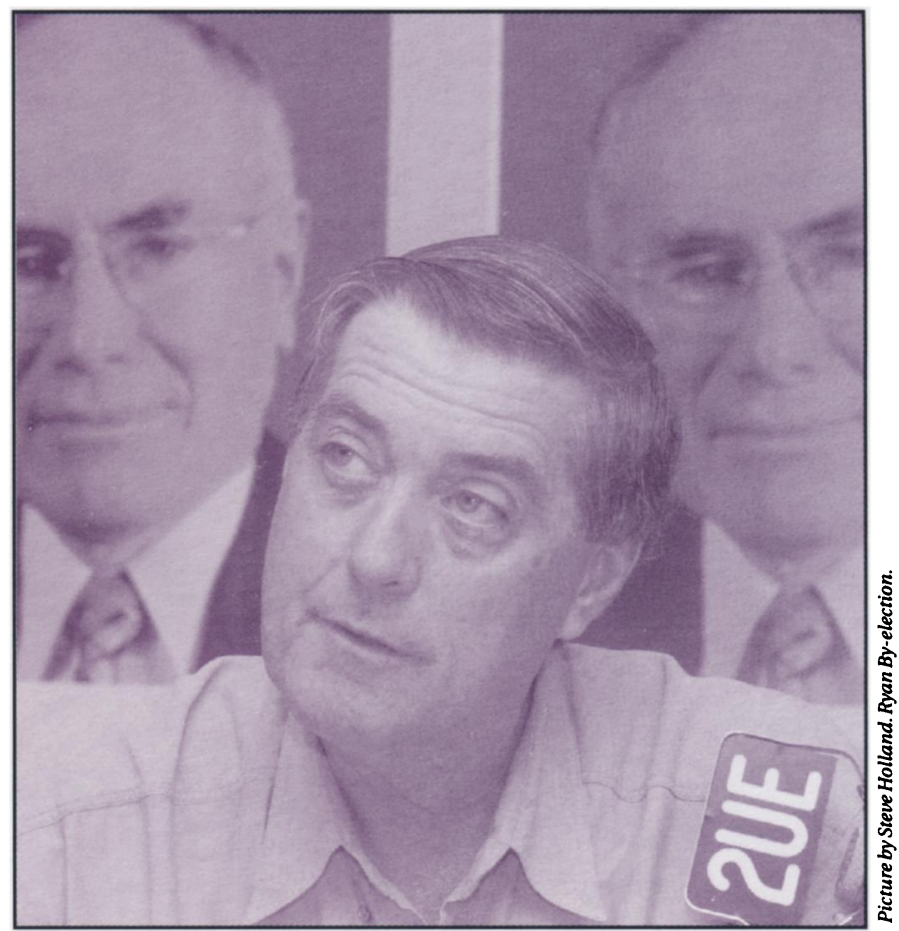


already suffered an extensive haemorrhaging of support at the 1998 state poll. This year, the Coalition's vote reached a nadir of 28.5 per cent, an amount shared evenly between the Liberal and National parties. In terms of representation, it is the Liberals who have suffered most. In holding only three seats, the Liberal vote has collapsed even in its heartland Brisbane and Sunshine Coast seats. A critical movement was also recorded against PHON. Several causes lie behind One Nation's lacklustre vote share of just 8.7 per cent (down 14.0 per cent). First, One Nation stood candidates in only 39 seats, half its 1998 field. Second, the Hanson group competed directly for populist right support with the City-Country Alliance (CCA), the bastard child of One Nation that split acrimoniously from the parent party in 1999. And third, PHON suffered the ignominy of continued negative publicity, including questions of financial accountability, police raids on its offices and, finally, deregistration as a party. PHON's primary vote in Queensland appears to have been derived almost entirely from the conservative parties and now rests at a level commensurate with its levels of support in Western Australia. This evidence suggests that support for the populist right peaked in the late 1990s and has now reached a plateau of around 10 per cent. Importantly, support for Independent and 'Other' party candidates surged in Queensland to 8.6 per cent (up 4.3 per cent), with five Independents now represented in the Legislative Assembly. On this evidence, the nonLabor forces in Queensland find themselves as fractured and as vulnerable as their Western counterparts, whereas the Queensland ALP, unlike its Western sibling, enjoys robust support.

\section{South Australia}

Although not due until early 2002, South Australia's state election is likely to occur before the federal poll later this year. This state, however, is likely to produce a different set of implications. In the absence of recent election results, this section relies upon the latest available public opinion data. The incumbent South Australian LNP Government has struggled for political ascendancy since being reduced to minority status at the 1997 election, despite winning 51.5 per cent of the two-party-preferred (2PP) vote. A recent Newspoll plotted Coalition support at 43 per cent with the ALP trailing at 37 per cent. In a pattern consistent with other states, 'Other' candidates are currently attracting around 20 per cent support. Local issues will undoubtedly dominate the campaign, with the health of the economy and the parlous state of the privatized electricity industry at the forefront. While the LNP's minority status and tenuous command of a vulnerable local economy augur badly for the Coalition, the ALP's feeble record in Opposition may offset any potential loss for the conservatives. The Newspoll data bears this out.

\section{The Federal Context}

Extrapolating isolated state results onto the federal arena is always hazardous. However, given the enormity of the electoral movements discussed above, in addition to the ALP's dominance in the more populous states of New South Wales and Victoria, several general inferences can be made as to the prognosis of the federal Coalition. In doing so, this section rounds out the analysis by factoring in those issues and developments most likely to bear influence on federal voting intention.

\section{Ryan By-election}

The result of the by-election for the federal seat of Ryan on 17 March 2001 provides further insight into the health of the federal Coalition. Caused by the unforced resignation of former Defence Minister, John Moore, the by-election became more than the usual litmus test for levels of party support. In what was a "blue-ribbon" Liberal seat since its creation in 1949, the Liberals' crisis began in 2000 amid accusations of ethnic branchstacking. Following a heated preselection, Liberal candidate, Bob Tucker, struggled in a campaign in which Prime Minister Howard made three personal appearances. Against mounting public hostility toward the issues discussed below, the ALP's Leonie Short, after a week of protracted counting, emerged the winner with a 9.7 per cent $2 \mathrm{PP}$ swing. Given that 54 Coalition seats would be lost to Labor in a uniform national swing of similar magnitude, dismay among Government Members is to be expected. Coalition morale could hardly have been lifted by recent public opinion polls that have plotted Coalition support consistently at less than 40 per cent. 


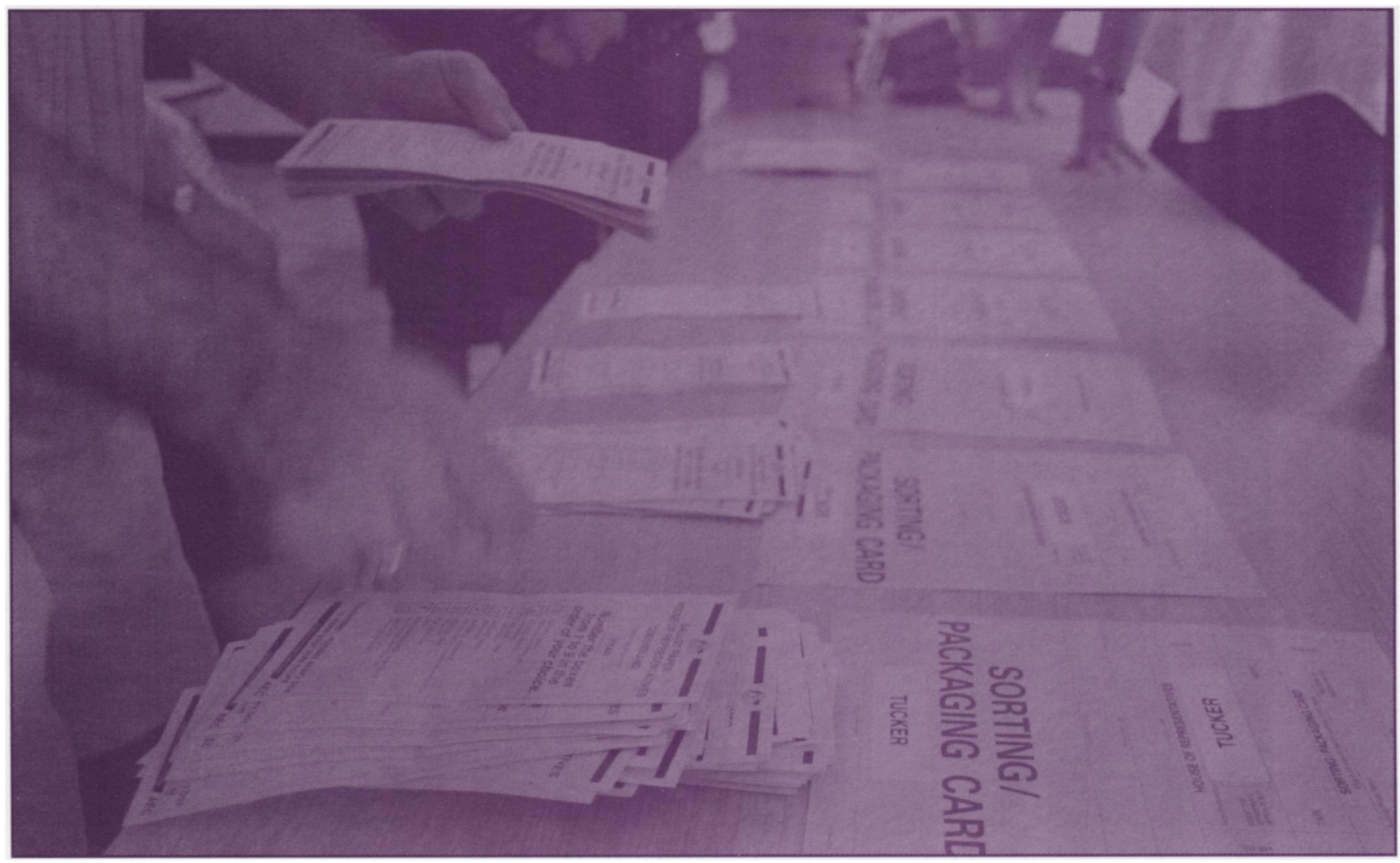

\section{...the evidence indicates that the Howard Government is set for a significant rebuff at the next federal election}

\section{Federal Issues}

The first issue, and of greatest potential as a source of voter anger, is the GST: the dominant theme of the 1993 and 1998 federal elections. Despite opinion polls in the post-implementation period indicating an overall endorsement of the new tax system, the impact of the GST appears to have eroded Coalition support on three fronts. First, the complexities faced by small business in completing the mandatory Business Activity Statements (BAS); second, the perceived "clawback" of the compensatory increase for pensioners; and third, the inflationary pressures themselves on the cost of living. While it was a key Coalition pledge that the impact of the GST would be shared equally across the community, paradoxically it is small business operators and pensioners - traditionally core Liberal Party constituents - who have articulated the loudest criticisms.

A second, and widely anticipated, issue is the cost of fuel. Again, while it is logical to assume that lower income voters would react most adversely, it appears that traditional conservative constituents - farmers, and multiple vehicle owners from leafy suburbs - are equally irate. The Ryan by-election result suggests that the Prime Minister's belated removal of automatic petrol price indexing did nothing to assuage conservative voters' wrath.

Central to the Prime Minister's vacillation on petrol pricing is a third issue: the question of leadership. Anecdotal evidence indicates that many voters saw Howard's move on fuel excise as little more than panicked capitulation on the hustings and, more critically, as a case of "too little, too late". Add to this similar "backflips" on the simplification of BAS and the taxing of family trusts and an image of weak, reactionary leadership emerges. Ironically, Howard's claim to 'strong' leadership may have been enhanced had he not yielded to base media pressure.

A fourth issue, and one central to the Coalition's reelection strategy, is the maintenance of the Government's credentials as prudent economic managers. Despite such positive indicators as low interest rates, the LNP Government's fiscal reputation has been battered by the falling Australian dollar. In addition, the Coalition's campaign war-chest has been severely compromised by the $\$ 1.3$ billion Budget shortfall following the lower-than-expected sale price of the $3 \mathrm{G}$ digital telephone network.

The perception of the Howard Government's lack of a longer term 'vision' constitutes a fifth issue. Mounting evidence suggests that traditional Liberal Party adherents residing in inner metropolitan "blueribbon" seats no longer subscribe to the Howard values so reminiscent of Menzian liberalism. Instead, it 


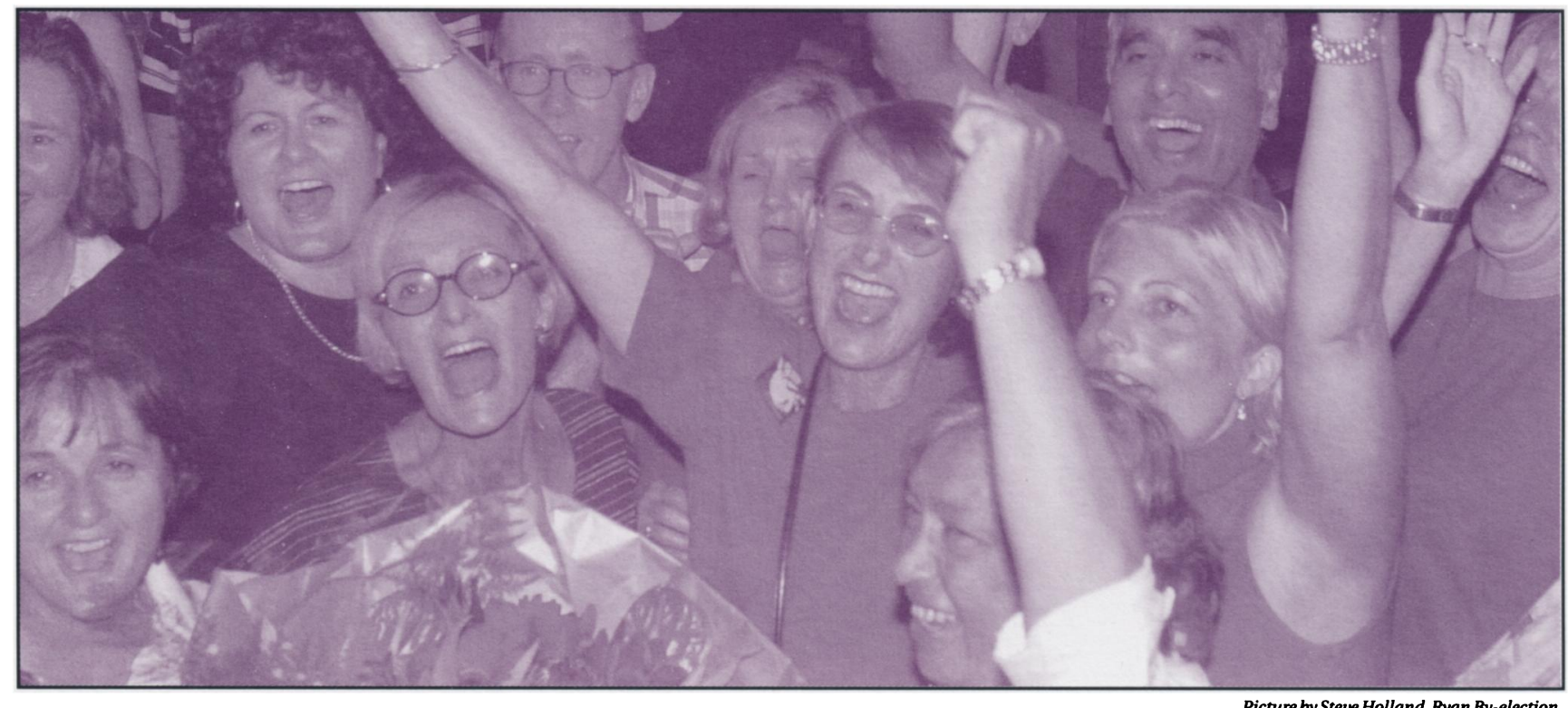

appears that inner-city Liberals are adopting progressive ideological positions closer to that of the ALP, particularly in terms of the Republic, immigration and Aboriginal Reconciliation. The majority 'Yes' vote in the electorates of Ryan and Bennelong - Howard's own electorate - at the 1999 Republican referendum support this hypothesis. Add to this any perception of Coalition pandering to PHON in the pursuit of second preferences and progressive urban Liberals will have been further alienated from the Howard campaign.

\section{the Liberal and National parties face a probable electoral catastrophe at the forthcoming federal election}

As outlined above, this article argues that leadership, while important, will be subsumed as an electoral determinant by the impact of issues and policy. This is supported by recent public opinion data on the "salience", or relevance, of key issues to voters. In surveying the importance voters attach to federal issues, for example, Newspoll found that leadership (58 per cent) ranked only eighth in a list of 15 nominated issues. Electors instead rated Education ( 77 per cent) and Health / Medicare (74 per cent) as their most pressing concerns: two issues on which the electorate has consistently regarded the ALP as the most competent managers. Critically, while surveys also indicate voters' superior confidence in the Coalition as sound economic managers, recent Newspoll data also reveal that such issues as taxation and industrial relations reform, and the maintenance of low inflation and interest rates, are of lesser importance to electors. In short, the Coalition's economic strengths are today less relevant to voters than are the social infrastructure issues of which the ALP has full command.

\section{Conclusion}

Five conclusions can be drawn from the above discussion. The first, and most apparent, is that the Liberal and National parties face a probable electoral catastrophe at the forthcoming federal election. The recent Western Australia and Queensland state election results support this assumption and suggest that the Coalition is suffering from fundamental image and policy difficulties that cut across state boundaries. Second, the fact that safe inner metropolitan Liberal seats, such as Ryan, have the potential to register record swings suggests that traditional Liberal Party identifiers are undergoing an ideological realignment, an outcome that augurs badly for the long-term future of the party. Third, while the ALP continues to perform well in Queensland, New South Wales andVictoria, data from Western Australian and South Australia suggest that the ALP cannot automatically be regarded as the primary beneficiary of anti-Coalition sentiment, although Australia's lower house preferential voting system will, however, ensure the ALP profits. This assumption tapers into a fourth conclusion: that the electorate's flirtation with minor parties and Independent candidates has yet to abate. Indeed, both PHON and the Greens may each procure additional Senators by virtue of that chamber's proportional representation voting system. Lastly, the increasing vote share attracted by minor players, and the magnitude of the electoral movements themselves, reveal that, above all else, the Australian electorate remains highly volatile. 


\section{Advisers, right or wrong}

1. Costello, Peter and John Fahey. Mid-Year Economic and Fiscal Outlook 2000-01, 15 November 2000

2. Reserve Bank of Australia. Statement on Monetary Policy, November 2000

\section{Media representations of the} Melbourne IT story

Chris Masters, veteran investigative journalist with the $\mathrm{ABC}$, interviewed on Arts Today, 14 November 2000.

2. "Domain Games" Four Corners, ABC TV, June 52000 (www.abc.net.au/4corners/ stories/s136215.htm <http://www.abc.net.au/4corners/stories/s136215.h $\mathrm{tm}>$ )

3. "Domain Games" Online forum (www.abc.net.au/ 4corners/sforum15/default.htm)

4. Simon Hughes, "Ah, the values of academia" The Age, June 52000 , p.T1.

5. Julie Wells, "Public interest sunk by floats" The Australian, June 72000, p.43.

6. Geoff Maslen, "IT float blurs public-private boundaries" Campus Review, June 7-13 2000, pp.1-2.

7. Geoff Maslen, "IT float blurs public-private boundaries" op cit; Geoff Maslen, "Kemp calls for report on float" Campus Review, June 14-20 2000, p.1 Julie Wells, "Public interest sunk by floats" op cit; Julie Wells, "Program floated fair questions" Campus Review, July 12-182000, p.11.

8. Stephen Bartholomeusz, "Melbourne IT review ignores commercial reality" The Age, June 22000 , p. B3.

Robert Shiller (2000) Irrational Exuberance, Scribe Publications, Melbourne

10. Eli Greenblat, "Investors dump Melbourne IT again" The Age, August 242000 , p.B5

11. Eli Greenblat, "University faces fire on IT float" The Age, June 2, 2000, p.1.

12. Grahame McCulloch, NTEU Melbourne IT Bulletin June 2000

13. Malcolm Maiden, "A-G on target with criticisms of Melbourne IT float" The Age, June 5 2000, p.B3.

14. Stephen Bartholomeusz, "Melbourne IT review ignores commercial reality" op cit

15. Auditor-General Report on Ministerial Portfolios, June 2000. (www.vicnet..net.au/ vicaud $1 / \mathrm{mp} 2000 / \mathrm{mp} 00$ summ.htm <http://www.vicnet.net.au/ vicaudl / mp2000/mp00summ.htm>)

16. Julie Wells, "Public interest sunk by floats" op cit

17. Simon Marginson (1997), Markets in Education, Allen \& Unwin, St Leonard's p.36.

18. Alan Gilbert, "Private uni funding is the price of excellence" The Age, April 6 2001, p.17; Gavin Brown "The rising cost of aiming high", The Australian, April 182001, p.33

19. Geoff Maslen, ""IT float blurs public-private boundaries" op cit

20. ABC Annual Report 1999-2000

21. JulieWe"ts, "Public interest sunk by floats" op cit

22. Misha Ketchell, "Uni students run riot in building" The Age, April 62001, p.8

The role of government in agricultural and pastoral land use

1. Commonwealth of Australia, 1992, National Strategy for Ecologically Sustainable Development http://www.environment.gov.au/psg/igu/nsesd/ind ex.html, Canberra.

2. Commonwealth of Australia, 2000, National Land and Water Audit Australia. http://www.nlwra.gov.au/, Canberra.

3. Toyne, P. and Farley, R., 1989, A national land management program: a joint ACF/NFF submission, Australian Journal of Soil and Water Conservation, $2(2), 6-9$ and Wahlquist, A., 2000, 'Land Forecast rubs
salt in the wound of farmer' (The Australian) 17th May 2000, pl3.

4. Mauldon, R. G. and Schapper, H. P., 1974, Australian Farmers Under Stress in Prosperity and Recession. Nedlands, Western Australia: University ofW.A. Press.

5. Government of Western Australia, 1996, Western Australian Salinity Action Plan.

6. Wilson, E. O., 1999, Consilience: the unity of knowledge New York: Vintage Books A Division of Random House, Inc.

7. Government of Western Australia, 2000, Natural Resource Management in Western Australia: The Salinity Strategy, prepared by the State Salinity Council, Western Australia.
The established principles of

\section{Cabinet Government}

1. Parkin A, Summers, J. \& Woodward, D., (1994) Government, Politics, Power and Policy in Australia 5th ed. Longman Cheshire, 4

2. Thynne, I \& Goldring, J., (1987) Accountability and Control: government officials and the exercise of power The Law Book Company, 45 and Simms, M. "Models of political accountability and concepts of Australian Government" in Australian Journal of Public Administration (1999), Vol 58, No 1, 34.

3. Parkin, Summers \& Woodward, 1999:4, \& Simms 1999:34.

4. Woodhouse, Diana, (1994), Ministers and Parliament: Accountability in theory and practice, Clarendon Press, Oxford, 3, Birch, A. H. (1964) "Responsibility in Britis Politics" in Geoffrey Marshall (ed), Ministerial Responsibility, Oxford University Press, Oxford, 1989: 26 and Parkin, Summers \&Woodward, 1999:4

5. Woodhouse, 1994:8

6. Woodhouse, 194:13

7. Encel, S. (1974) Cabinet Government in Australia 2nd ed. Melbourne University Press, Carlton, 117 and Morley, Lord (1889) "The principles of cabinet Morley, Lord (1889) "The principles of cabinet
government" in Geoffrey Marshall (ed) Ministerial government" in Geoffrey Marshall (ed) Ministerial
Responsibility, Oxford University Press, Oxford, 1989:17

8. Woodhouse, 194:3

9. Mackintosh, J. P., (1962) "The British Cabinet" in S. Encel (1974) Cabinet Government in Australia 2nd ed. Melbourne University Press, Carlton, 445-446.

10. Woodhouse, 194:33 and Marshall, Geoffrey (1986) "Individual Responsibility" in Geoffrey Marshall (ed) Ministerial Responsibility, Oxford University Press, Oxford, 1989, 131 .

11. Woodhouse, 194:33 and Encel, 1974:116.

12. Woodhouse, 194:33

13. Thompson, E. \& Tillotsen, G. "Caught in the act: The smoking gun view of ministerial responsibility" in the Australian Journal of Public Administration (1999), Vol 58, NO $1,49$.

14. Encel, 1974:134.

15. Encel, 1974:134

16. Morley, 1889:17

17. Finer, S. E. (1956) "The individual responsibility of ministers" in Geoffrey Marshall (ed) Ministerial Responsibility, Oxford University Press, Oxford, 1989:120.

18. Encel, 1974:107.

19. Ellis, D. L. (1980) "Collective ministerial responsibility and collective responsibility" in Geoffrey Marshall (ed) Ministerial Responsibility, Oxford University Press, Ministerial Resp
Oxford, 1989:52.

20. Encel, 1974:107.

21. Encel, 1974:113

22. Ellis, 1989:49.

23. Encel, 1974:107.

24. Encel, 1974:113

25. Ellis, $1989: 48$.

26. Encel, 1974:124

27. Hunt, Lord of Tanworth (1980) "Access to a previous government's papers" in Geoffrey Marshall (ed) Movinisterial Responsibility, Oxford University Press, Oxford, 1989:72.

28. Parkin, Summer \& Woodward, 1994:133 and Funnell, W., (2001), Government by Fiat: Retreat from Responsibility, UNSW Press, Sydney, 14

29. Funnell, 2001: 142

\section{State swings spell Howard's end}

1. ForWestern Australia results, see http://www.waec.wa.gov.au

2. For Queensland results, se

http://www.ecq.qld.gov.au

3. For South Australian results, see http://www.seo.sa.gov.au

4. October - December 2000. See http://www.newspoll.com.au

5. Seehttp://www.aec govau

6. M. Mackerras. The Australian. 3 January 2001, p. 4

The Australian, 27 March 2001, p. 2

The Australian, 27 March 2001, p. 2 .

8. The Australian, 23 March $2001, p .1$.
9. For public opinion on the salience of Federal Issues, see http://www.newspoll.com.au

The Australian Democrats... dead in the water?

1. Bean, C, in J. Warhurst, Keeping the Bastards Honest, 1997, Allen \& Unwin, page 77
2. The Parliamentary Handbook of the Commonwealth of Australia, 28 ed, 1999, pp 290-299.

\section{Hardline or moderate? Peter}

Costello on the welfare state.

1. See, for example, Aubin, T, Peter Costello: A Biography, 1999, Harper Collins, Sydney, pp. 136, 163, 240, 292.

2. Aubin, op.cit, p. 292; Carney, S, “A farewell to youth heralds call to arms", The Age, 9 August 1997. See also McGregor, R, "Rebels walk softly and carry a big agenda", The Australian, 6 April 2000; Henderson, G. "Costello's poser: who's out of step?", The Age, 5 December 2000.

3. Costello, P, "Labor's shameful legacy", The Bulletin, 28 February 1995, p. 22

4. Costello, $P$, "The Liberal Party and its future", Australian Quarterly, 65(3), 1993, pp. 23\&26.

5. Costello, P, "Social Partnerships in an Opportunity Society", Options, no. 12, December 2000, p. 6.

6. Costello, P, Address to the Melbourne City Mission, 11 August 2000. See also Costello, P. The Australian Taxation System in Need of Reform, 1998, AGPS, Canberra, 1998, p.2.

7. Costello, P, "Economic Liberalism and the Path to Prosperity" in Alan Gregory (ed.), The Menzies Lectures 1978-1998, 1999, Sir Robert Menzies Lecture Trust, Melbourne, p. 336

8. Aubin, op.cit, p.240

9. Wiseman, J, Global Nation? 1998, Cambridge University Press, Melbourne, p. 64.

10. Mendes, P, "Globalisation and the Welfare State. From the Local to the International", Policy, Organisation \& Society, 19(1), 2000, p.132.

11. Aubin, op.cit, p.240. Also see Hudson, P. 'Costello rules out dole cuts", Herald Sun, 2 August 1996

12. ACOSS Impact, September 1996

13. Mendes, $\mathrm{P}$, "Reconstituting the Public as the Private: John Howard on the Welfare State", Journal of Economic and Social Policy, 4(2), 2000, p.38.

14. Quoted in Kitney, G, "Will This Peter Play Paul?", Age Good Weekend, 30 April 1994, p. 22.

15. Address to Melbourne City Mission, op.cit.

16. Mendes, "Reconstituting". Op.cit, p.41

17. Costello, "The Liberal Party", op.cit, pp.20, 25. See also Aubin, op.cit, pp. 145

18. Mendes, “Reconstituting", op.cit, pp.34-35.

Human rights under the Australian

\section{Constitution}

Rawls, John, 1972, A Theory Of Justice, Clarendon Press, Oxford, 136-137.

2. Williams, 1999:68.

3. (1997), 190 Commonwealth Law Report (CLR) 1 .

4. (1998), 152 Australian Law Report (ALR) 540

5. Williams, 1999:68

6. (1992) 177 CLR 106

Gallagherv Durack (1983) 152 CLR 238

Williams, 1999:166.

. Williams, 1999:168.

10. Melbourne Corporation v Commonwealth (1947) 74 CLR 31. This comparison has particular poignance considering the important work Williams has done analysing the relationship between the implied freedom of political communication and the implied State protections established under the Engineer's principle: see "Engineers is Dead, Long Live the principle: see "Engineers is Dead, Long Live the Engineer!' (1995) 17 Sydney Law Review 62 . Williams does,

11. (1992) 177 CLR 1

12. Theophanous $v$ Herald \& Weekly Times (1994) $182 \mathrm{CLR}$ 211; Lange v Australian Broadcasting Corporation (1997) 189 CLR 520.

13. With the honourable exception of the $\mathrm{ABC}$, defendant in Lange.

14. (1996) 186 CLR 302. See also Muldowney $v$ South Australia (1996) 186 CLR 352.

15. (1996) 186 CLR 140

16. (1997) 154 ALR 674

17. (1994) 182 CLR 272

18. (1997) 189 CLR 579

19. Not that Williams is the only person to have done so; indeed the inclusion of 117 in any list of 'rights' under the Constitution is traditional.

20. For example, Lee Fay $v$ Vincent (1908) 7 CLR 389

21. Street $v$ Queensland Bar Association (1989) $168 \mathrm{CLR}$ 461. 